\title{
Faktor-Faktor Penyebab Penyimpangan dalam Penafsiran Al-Quran
}

\section{Noblana Adib}

Universitas Islam Negeri Syarif Hidayatullah Jakarta, Indonesia

noblana_adib@yahoo.com

\begin{abstract}
Abstrak: Mufasir menafsirkan al-Quran seharusnya bukan disesuaikan dengan kehendak mufasir, tetapi harus sesuai dengan kehendak Dzat yang memfirmankan al-Quran. Mufasir harusnya dalam menafsirkan al-Quran menggunakan prinsif kehati-hatian. Jadi kepribadian mufasir menjadi sangat dibutuhkan karena sikap subjektivitas dari si mufasir berpengaruh besar terhadap penafsiran. Kemudian Kuatnya pengaruh aliran yang mendominasi pemikiran mufasir sehingga ia senantiasa berusaha mengerahkan seluruh kemampuan dan daya pikirnya dalam menafsirkan ayat al-Quran supaya cocok dengan paham yang dianutnya.
\end{abstract}

Kata kunci: Kepentingan, Penafsiran, Al-Quran 


\section{A. Pendahuluan}

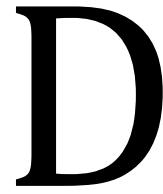
ede Ahmad Ghazali dan Heri Gunawan mengemukakan dalam bukunya Studi Islam Suatu Pengantar dengan Pendekatan Interdisipliner mengemukakan bahwa hal yang terpenting dalam studi tafsir al-Quran adalah bagaimana menafsirkan al-Quran bukan sesuai dengan kehendak Mufasir, tetapi harus sesuai dengan kehendak Dzat yang memfirmankan al-Quran itu. Jika menafsirkan al-Quran sesuai dengan keinginan Mufasir pasti akan ditemukan berbagai kejanggalan dalam menafsirkannya. Namun, jika sesuai dengan kehendak atau maksud Allah, Mufasir akan lebih berhati-hati dalam menafsirkan al-Quran tersebut. ${ }^{1}$

Lebih lanjut Ghazali dan Gunawan menjelaskan pengertian tafsir, keduanya menjelaskan bahwa istilah tafsir merupakan bentuk mashdar dari kata fassara yufassiru tafsiiran yang berarti keterangan atau uraian. Mengutip Rosihan Anwar, Ghazali dan Gunawan lebih lanjut menjelaskan Al-Jurjani mengatakan kata tafsir secara etimologi bermakna al-kasyaf atau al-idzhar yang oleh para ahli bahasa diartikan sebagai menyingkap atau melahirkan. Secara terminologis, al-Kilabi mengatakan, tafsir adalah uraian yang menjelaskan al-Quran, menerangkan maknanya dan menjelaskan apa yang dikehendaki dengan nash, isyarat atau tujuannya. Sementara itu al-Jajari dalam alTaujih mengatakan tafsir pada hakikatnya adalah penjelasan lafadz yang sukar dipahami oleh pendengar dengan mengemukakan lafadz sinonimnya atau makna yang mendekatinya, atau dengan jalan mengemukakan salah satu dzilalah lafdzi. ${ }^{2}$

Masih mengutip Anwar, Ghazali dan Gunawan mengemukakan sementara itu, Abu Hayyan mengatakan tafsir adalah ilmu mengenai cara mengucapkan petunjuk, kandungan-kandungan hukum, dan makna-makna yang terkandung di dalamnya. AlZarkasy mengatakan tafsir adalah ilmu yang digunakan untuk memahami dan menjelaskan makna-makna kitab Allah yang diturunkan kepada Nabi-Nya, Muhammad serta menyimpulkan kandungan-kandungan hukum dan hikmahnya. ${ }^{3}$

Sekali lagi Ghazali dan Gunawan menekankan definisi tafsir yang mereka kemukakan dapat menunjukkan cara untuk memahami al-Quran dengan cara interpretasi, penakaran, dan ijtihad terhadap nilai-nilai makna, maksud dan tujuan serta

1 Dede Ahmad Ghazali dan Heri Gunawan, Studi Islam Suatu Pengantar Dengan Pendekatan Interdisipliner, (Bandung: PT Remaja Rosdakarya, 2015), pp. 105-106.

${ }^{2}$ Ibid., p. 106.

${ }^{3}$ Ibid. 
hikmah yang terkandung di dalam al-Quran. Tujuan utamanya agar kita dapat memahami al-Quran sesuai dengan keinginan yang memfirmankannya. ${ }^{4}$

Selanjutnya, Nashruddin Baidan ${ }^{5}$ mengemukakan bahwa menurutnya dalam rentangan waktu yang demikian panjang jelas terjadi berbagai perubahan dan perkembangan yang amat menonjol dalam kajian penafsiran al-Quran sampai ke abad modern sebagaimana kita saksikan dewasa ini. Sejalan dengan itu, maka ilmu tafsir pun seyogyannya juga ikut berkembang. Usaha ke arah ini sampai abad modern, bahkan hampir memasuki millennium ketiga ini belum dilakukan padahal kondisi real umat kita telah amat membutuhkannya. ${ }^{6}$ Baidan dengan mengarang bukunya Rekonstruksi Ilmu Tafsir berharap akan didapatkan wawasan baru dalam penerapan ilmu ini sehingga diperoleh penafsiran al-Quran yang lebih kondusif dengan tuntutan zaman yang semakin kompleks, terutama dalam millennium ketiga yang sudah diambang pintu. Dengan begitu akan terasa bahwa al-Quran selalu updated dan tak pernah out of dated, serta akan senantiasa menarik bagi umat yang hidup di abad ini, lalu umat termotivasi untuk menjadikan al-Quran sebagai satu-satunya pedoman hidup dalam menjalani kehidupan di muka bumi ini. Dengan begitu, kita berharap semoga umat akan terbimbing ke jalan yang benar sehingga al-Quran betul-betul menjadi Imam dalam semua aspek kehidupan mereka; baik individu, berkeluarga, bermasyarakat dan berbangsa. $^{7}$

Lebih lanjut Baidan menekankan dan mengkategorikan kepribadian Mufasir menjadi sangat dibutuhkan karena sikap subjektif dari si Mufasir berpengaruh besar terhadap penafsiran. Terjadinya berbagai penyimpangan atau kekeliruan dalam proses penafsiran, banyak berawal dari sikap subjektif Mufasir yang terlalu menonjol sehingga seakan-akan al-Quran yang mengikuti pendapat Mufasir, bukan sebaliknya Mufasir yang harus mengikuti al-Quran. Dengan dikajinya kepribadian Mufasir secara seksama maka seseorang yang bermaksud menafsirkan suatu ayat dapat mempelajari sikap yang harus dipunyai oleh seorang Mufasir sebelum kegiatan penafsiran dilakukan. Dengan begitu

\footnotetext{
${ }^{4}$ Ibid..

${ }^{5}$ Prof. Dr. Nashruddin Baidan lahir di Lintau, Sematera Barat 5 Mei 1951 adalah dosen ilmu tafsir kajian-kajian Baidan dalam ilmu tafsir adalah Metodologi Penafsiran al-Quran (1998) dan Tafsir bi al-Ray (Upaya penggalian Konsep wanita dalam al-Quran) kemudian Wawasan Baru Ilmu Tafsir dan Solusi Qur'ani Terhadap Berbagai Permasalahan Sosial Kontemporer. Nashruddin Baidan, Rekonstruksi Ilmu Tafsir, (Jakarta: PT Dana Bhakti Prima Yasa, 2000), p. 107.

${ }^{6}$ Ibid., p. 4.

${ }^{7}$ Ibid., p. 5.
} 
dia akan terbimbing secara baik dalam proses penafsiran al-Quran ayat demi ayat dan surat demi surat. 8

Sementara itu, Islah Gusmian ${ }^{9}$ mengemukakan dan mengakui bahwa sebuah karya tafsir dilihat dari episteme yang terbangun dan arah gerak di dalamnya, tidak lepas dari ruang sosial, dimana dan oleh siapa tafsir itu ditulis. Ruang sosial ini, dengan keragaman problem dan dinamikanya, disadari atau tidak, selalu saja akan mewarnai karya tafsir, sekaligus merepresentasikan kepentingan dan ideologi ${ }^{10}$ yang ada. ${ }^{11}$

Gusmian menjelaskan pemikiran Abu Zayd dengan membaca penelitian Nur Ichwan, menurut Abu Zayd dalam konteks semacam ini, Abu Zayd mengingatkan dan sekaligus mengkritik keras bentuk-bentuk tafsir ideologis. Pengertian ideologi yang Abu Zayd maksud cukup beragam. Di satu kesempatan, dia gunakan dalam pengertian yang ketat, yaitu kesadaran kelompok untuk melindungi kepentingan mereka berhadapan dengan kelompok lain dalam suatu masyarakat. Kadang juga dalam pengertian manipulasi politis terhadap makna teks. Namun, secara umum klaim ideologi yang dipakainya itu merujuk pada adanya bias, kepentingan, orientasi, dan tujuan-tujuan politis pragmatis serta keagamaan dalam sebuah karya tafsir. Itu sebabnya, dia tidak mengkronfrontasikan objektivitas dengan subjektivitas sebagaimana lumrahnya, tetapi mengkonfrontasikan objektvitas dengan kecenderungan ideologis. ${ }^{12}$

Lebih lanjut Gusmian mengemukakan ideology di sini, oleh Abu Zayd lebih diletakkan sebagai masalah epistemologis yang terkait dengan level kebenaran yang meyakinkan (al-haqâ'iq al-yaqîniyyah) pada suatu masa dalam suatu kebudayaan tertentu. Kebenaran ini menurut dia, secara absolut bersifat relatif dan bisa berubah disebabkan oleh perubahan yang terjadi di dalam kesadaran manusia. Epistemology

\footnotetext{
${ }^{8}$ Ibid, p. 33.
}

${ }^{9}$ Islah Gusmian adalah dosen di Fakultas Ushuluddin dan Dakwah IAIN Surakarta. Pada 2006 dinobatkan sebagai peneliti terbaik I, Dosen PTAI se-Indonesia, oleh Direktorat Jendral Pendidikan Agama Islam Departemen Agama RI. Pada tahun yang sama oleh lembaga yang sama dinobatkan sebagai dosen berprestasi di STAIN Surakarta.

${ }^{10}$ Islah Gusmian mengemukan penggunaan klaim ideologis yang ia gunakan adalah di samping pada pengertian di mana suatu tafsir yang secara epitemologis tidak mempunyai dasar pijak pada teks alQur'an, seperti diintrodusir Abû Zayd, juga dalam pengertian visi dan gerak karya tafsir. Pengertian yang terakhir ini, menyangkut medan audiens dan konteks-konteks dari sebuah karya tafsir, yang disajikan: bisa berupa rezim, komunitas, wacana dan yang lain, yang berpengaruh pada episteme dan gerak wacana suatu karya tafsir. Medan audiens dan konteks-konteks sosial ini juga ikut membentuk suatu narasi suatu narasi teks tafsir yang beragam sebagai salah satu dasar dari visi karya tafsir. Islah Gusmian, Khazanah Tafsir Indonesia dari Hermeneutika hingga Ideologi, (Yogyakarta, LKiS, 2013).

${ }^{11}$ Ibid., p. 319.

${ }^{12}$ Ibid. 
dalam pengertian kultural, merujuk pada kesadaran sosial bersama, meskipun terdapat keragaman manusia. Intinya, bisa disimpulkan, dia tidak sepakat dengan model penafsiran yang secara epistemologis tidak mempunyai dasar pijak pada teks al-Quran itu sendiri. ${ }^{13}$ Untuk memperjelas bagaimana idiology mempengaruhi penafsiran terhadap al-Quran, Gusmian dalam bukunnya merinci dan mencontohkan bagaimana gagasan serta arah gerak karya tafsir secara diam-diam telah termuati episteme yang terbangun dalam ruang sosial di mana karya tafsir ditulis. Gusmian dalam mengungkapkan itu secara epistemologis memanfaatkan mekanisme analisis yang dilakukan Abu Zayd: membedakan antara wilayah makna, signifikansi dan ruang yang tak terkalahkan di dalam teks. ${ }^{14}$ Lebih lanjut di samping, memanfaatkan analisis wacana kritis untuk membongkar kepentingan yang tersembunyi di balik narasi yang disajikan penulis tafsir. Pembongkaran ini melalui model narasi karya tafsir dalam wilayah teksnya, baik gaya bahasa yang di pakai dengan berbagai citraan-citraan yang dibangun, maupun contoh-contohnya yang ditampilkan sebagai variabel penjelas terhadap tematema yang dikaji. ${ }^{15}$

Maka untuk memperjelas makalah yang berjudul Faktor-Faktor Penyebab Penyimpangan dalam Penafsiran Al-Quran sub babnya akan di fokuskan pada Kriteria dan syarat-syarat mufasir, Ilmu-Ilmu Bantu dalam menafsirkan Al-Quran

Faktor-Faktor Penyebab Penyimpangan dalam Penafsiran Al-Quran, Pentafsiran al-Quran memuat kepentingan: dalam hal ini akan saya bagi tiga point yaitu: Pentafsiran al-Quran bermuatan kepentingan: sederhana, Pentafsiran Ayat al-Quran Berbeda Kepentingan: Komplek, Pentafsiran Al-Quran dan Realitas Umat: Fakta dan Nasehat Ahmad Syafii Maarif dan Terakhir Kesimpulan.

\section{B. Kriteria dan Syarat-Syarat Mufasir}

Ghazali dan Gunawan memperjelas kriteria dan syarat-syarat mufassir dengan mengutip banyak ilmuan tafsir seperti Mana Khalil al-Qathan dalam Mabhits fi Ulum alQuran mengemukakan beberapa kriteria mufasir, di antaranya adalah sebagai berikut:

1. Berniat baik dan bertujuan benar. Niat yang baik akan memengaruhi terhadap amal perbuatan, atau dengan kata lain, amal perbuatan itu tergantung pada niat;

\footnotetext{
${ }^{13}$ Ibid., p. 320.

${ }^{14}$ Ibid., p. 321.

${ }^{15}$ Ibid.
} 
2. Memiliki akhlak yang baik. Akhal yang baik harus senantiasa dimiliki oleh seorang mufasir Karena mufasir bagaikan pendidik yang itu sangat memengaruhi terhadap jiwa seseorang;

3. Taat dan beramal. Ilmu akan dapat diterima oleh khalayak, melalui orang yang mengamalkannya. Ketimbang dari pada mereka yang memilki ketinggian pengetahuan dan kecermatan kajiannya (tanpa disertai dengan amal);

4. Berlaku jujur dan teliti dalam penukilan. Hal ini sangat penting untuk menjaga akurasi dan keshahihannya pendapatnya, sehingga mufasir tidak berbicara atau menulis kecuali telah melakukan penyelidikan terhadap apa yang diriwayatkannya;

5. Bersikap tawadhu dan lemah lembut karena kesombongan ilmiah merupakan dinding yang kokoh yang menghalangi seorang alim dengan kemanfaatan ilmunya;

6. Berjiwa mulia. Menjaga diri selalu berjiwa mulia dengan cara menjaga diri dari halhal yang remeh serta tidak mengelilingi pintu-pintu kebesaran dan menguasai bagi peminta-minta yang buta;

7. Vokal dalam memyampaikan kebenaran karena jihat yang paling baik adalah menyampaikan yang hak dihadapan penguasa yang zalim. Bukankah terdapat pepatah: "katakanlah yang haq walau itu terasa pahit";

8. Menjaga penampilan sehingga dapat menjaga kewibawaan mufasir dan kehormatan dalam segala penampilannya. Juga dalam cara duduk, berdiri dan berjalan. Akan tetapi, hal ini syogianya tidak dipaksakan;

9. Bersikap tenang dan mantap. Mufasir hendaknya tidak tergesa-gesa dalam berbicara, tetapi ia hendaknya bersikap tenang, mantap dan jelas;

10. Mendahulukan yang lebih utama dari pad dirinya. Hendaknya tidak gegabah menafsirkan sesuatu dihadapan orang yang lebih pandai pada waktu mereka masih hidup dan tidak merendahkan meraka yang telah wafat;

11. Menempuh dan menetapkan langkah-langkah penafsiran dengan baik. Seperti memulai dengan menyebutkan asbabun nuzul, arti kosa kata dan lain sebgainya. ${ }^{16}$ Lebih lanjut masih mengutip Al-Qathan, Ghazali dan Gunawa memnyebutkan beberapa syarat yang harus dipenuhi oleh seorang mufasir. Dalam tulisannya Al-Qathan meringkas menjadi sembilan syarat-syarat yang harus dipenuhi oleh mufasir ketika

${ }^{16}$ Ghazali dan Gunawan., Studi Islam Suatu, p.106-107. 
akan menafsirkan al-Quran. Berikut ini merupakan penjelasan dari syarat-syarat seorang mufasir.

1. Memiliki kaidah yang benar.

Seseorang yang akan menafsirkan al-Quran harus memiliki aqidah yang benar. Akidah sangat memengaruhi jiwa pemiliknya dan seringkali mendorong untuk mengubah nash-nash dan berkhianat dalam penyampaian berita. Apabila seseorang menyusun sebuah kitab tafsir, ditakwilkan ayat-ayat yang bertentangan dengan akidahnya, dan membawanya padamazhabnya yang batil guna memalingkan manusia dari mengikuti golongan salaf dan dari jalan petunjuk

2. Bersih dari hawa nafsu

Seorang mufasir harus bersih dari hawa nafsu, karena hawa nafsu akan mendorong pemiliknya untuk membela mazhabnya sehingga ia menipu manusia dengan katakata halus dan keterangan menarik

3. Terlebih dahulu menafsirkan al-Quran dengan al-Quran

Dalam menafsirkan al-Quran terlebih dahulu menafsirkan dengan al-Quran. Karena sesuatu yang masih global pada sesuatu tempat telah diperinci pada tempat (ayat) lain dan sesuatu yang dikemukakan secara ringkas pada suatu tempat telah diuraikan pada tempat (ayat) yang lain.

4. Menafsirkan dari Sunnah

Kemudian menafsirkan al-Quran dengan sunnah, karena sunnah berfungsi sebagai pensyrahan (penjelasan) al-Quran. Al-Quran telah menyebutkan bahwa segala hukum (ketetapan) Rasulullah adalah berasal dari Allah.

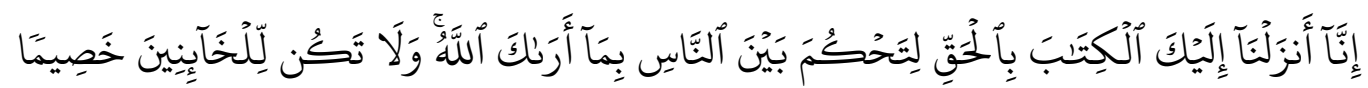

Artinya: "sesungguhnya kami telah menurunkan kitab (al-Quran) kepadamu (Muhammad) dengan membawa kebenaran, agar engkau mengadili antara manusia dengan apa yang telah diajarkan Allah kepadamu, dan janganlah engkau menjadi penantang (orang yang tidak bersalah), karena (membela) orang-orang yang berhianat (QS. An-Nisa ayat 105). ${ }^{17}$

5. Meninjau para sahabat

17 Ayat ini dan beberapa ayat berikutnya diturunkan berhubungan dengan pencurian yang dilakukan Thu'mah dan ia Menyembunyikan barang curian itu di rumah seorang Yahudi. Thu'mah tidak mengakui perbuatannya itu malah menuduh bahwa yang mencuri barang itu orang Yahudi. hal ini diajukan oleh kerabat-kerabat Thu'mah kepada Nabi s.a.w. dan mereka meminta agar Nabi membela Thu'mah dan menghukum orang-orang Yahudi, Kendatipun mereka tahu bahwa yang mencuri barang itu ialah Thu'mah, Nabi sendiri Hampir-hampir membenarkan tuduhan Thu'mah dan kerabatnya itu terhadap orang Yahudi. 
Apabila tidak ditemukan penafsiran dalam sunnah, hendaknya meninjau pendapat para shabat, karena lebih mengetahui tentang tafsir al-Quran. Mengingat merekalah yang menyaksikan qarinah dan kondisi ketika al-Quran diturunkan, di samping mereka memiliki pemahaman yang sempurna ilmu yang shahih dan amal yang saleh.

6. Memeriksa pendapat para tabi'in

Apabila tidak juga ditemukan penafsiran dalam al-Quran, sunnah maupun pendapat para sahabat sebaliknya memeriksa pendapat para tabi'in, sebagaimana dilakukan oleh para ulama.

7. Menguasai pengetahuan bahasa Arab dengan segala cabangnya

Al-Quran diturunkan dalam bahasa arab, maka pemahaman tentangnya akan sangat tergantung pada penguraian mufrodat (kosa kata) lafaz-lafaz dan pengertianyang ditunjukannya.

8. Menguasai pokok-pokok ilmu yang berkaitan dengan al-Quran

Ilmu-ilmu pokok yang berkaitan dengan al-Quran, seperti ilmu qiro'ah karena dengan ilmu ini ketahui bagaimana cara pengucapan lafadz-lafadz al-Quran dan dapat memilih mana ragam bacaan al-Quran yang paling yang diperkenankan. Ilmuilmu yang berkaitan dengan al-Quran juga seperti ilmu Asbab-an- uzul, Nasikh Mansukh Makky dan Madany, dan yang lainnya

9. Memiliki pemahaman yang cermat

Mufasir yang memiliki pemahaman yang cermat akan mengukuhkan pemahamannya atas suatu makna ke makna lainya atau menyimpulkan makna yang sejalan nash-nash syariat. ${ }^{18}$

Baidan juga dalam bukunya merinci kepribadian sorang Mufasir yang menurut harus dimiliki seorang Mufasir. Kepribadian ialah sifat hakiki yang tercermin pada sikap seseorang atau suatu bangsa yang membedakan dirinya dari orang atau bangsa lain. Berangkat dari pengertian itu, maka yang dimaksud dengan kepribadian mufasir ialah watak atau sikap mental dari seseorang mufasir seperti akidahnya, keikhlasannya dan lain-lain. Baidan lebih lanjut mengemukakan bahwa kajian tentang unsur ini di masa lalu tidak begitu popular. Karena mayoritas ulama tafsir tidak memberikan perhatian yang berarti terhadapnya, kecuali Al-Suyûthi di dalam al-Itqân. Namun Al-Suyûthi

${ }^{18}$ Ghazali dan Gunawan, Studi Islam, pp. 108-9. 
menurut Baidan tidak menyebutnya dengan kepribadian mufasir sebagaimana Baidan mengkategorisasikannya, Al-Suyûthi menyebutnya "mengenal syarat-syarat seorang mufasir". Maka dari itu Baidan yakin bahwa fakta ini adalah penyebab banyak ulama yang tidak menggap kajian kepribadian mufasir itu sesuatu yang urgen. Agaknya mereka berasumsi, bila seorang mufasir telah menguasai kaedah-kaedah penafsiran dengan baik, dan memahami pula jati diri al-Quran ${ }^{19}$ secara komprehensif, maka kajian tentang kepribadian mufasir tidak begitu penting. Anggapan semacam ini sulit sekali untuk diterima karena suatu karya tafsir, bagaimanapun wujudnya, apakah melalui metode global, analitis, komparatif atau tematik semua itu tidak dapat bebas secara penuh subjektifitas dirinya: bahkan tafsir bi al-ma'tsûr sekalipun masih ada muatan subjektif mufasirnya meskipun amat kecil..20

Kepribadian yang pertama yang di wajibkan Baidan adalah seorang mufasir harus mempunyai akidah yang benar (itikad baik) maka menurutnya ada empat hal utama yang harus dimilikinya yaitu ikhlas, netral sadar dan ilmu mawhibah, berikut penjelasannya satu persatu:

1. Ikhlas, setelah mufasir bebas dari paham atau aliran dapat membelokkannya dari jalan yang benar maka ia harus meluruskan niatnya. Artinya dia menafsirkan alQuran itu semata-mata karena Allah, tidak didorong oleh motivasi mencari keuntungan-keuntungan duniawi, baik untuk kepentingan diripribadinya, keluarga, maupun golongan dan sebagainya. Kemudian, Untuk memperoleh ilmu yang dibutuhkan oleh umat yang terdapat di dalam al-Quran. Maka mufasir harus tuntunan langsung dari Tuhan yang menurunkan firman itu, meminta langsung kepada tuhan itu merupakan salah satu bentuk ikhlas dalam proses penafsiran alQuran. Yaitu orang yang berbuat, berpikir, beribadah dan sebagainya demi mengharapkan keridaan Allah semata. Apabila mufasir telah mempunyai mental

19 Baidan membagi spesifikasi unsur-unsur Ilmu tafsir dibagi dua salah satunya komponen eksternal. Salah satu komponen eksternal adalah jati diri al-Quran. Jati diri ialah ciri-ciri gambaran atas keadaan khusus seseorang atau benda, identitas, inti dan sebagainya. Berdasakan pengertian itu, maka yang dimaskud dengan jati diri al-Quran seperti sejarahnya, qiraat-nya, munasabat-nya, kemukjizatannya, dan semantik-nya. Lihat, Nashruddin Baidan, Rekonstruksi..., pp. 21-9.

${ }^{20}$ Lihat, Nashruddin Baidan, Rekonstruksi..., pp. 32-3; dan Latifatul Khasanah, pada makalahnya berjudul Tafsir bi al-Ma'tsur, bi al-Ra'yi da bi al-Isyari menjelaskan kelemahan ketiga metode ini, dan jika di pahami kelemahannya bisa di pahami sebagai fator-faktor kesalahan dalam pentafsiran Al-Quran. Kelemahan Tafsir bil Mat'tsur, adalah banyak riwayat yang disisipkan oleh musuh-musuh Islam, Bercampur baurnya riwayat-riwayat yang shahih dengan tidak shahih. Kelemahan metode Tafsir bi al Ra'yi, dan Tafsir bi al-Isyari keduanya hampir sama yaitu penafsiran yang dipaksakan dan sangat terlihat subjektifitas si mufasir (Jakarta: UIN Syarif Hidayatulah, 2017) pp. 22-4. 
seperti ini, besar kemungkinan penafsirannya lebih objektif dan mendekati kebenaran yang dimaksudkan Allah. Hal itu bisa terjadi karena seseorang yang ikhlas beramal. Tidak pernah mencari keuntungan pribadi atau golongan ataupun yang lain. Tetapi semata-mata mendambakan ridha Allah SWT. ${ }^{21}$

2. Netral, yang dimaksud dengan netral di dalam kajian ini menurut Baidan adalah mufasir tidak boleh memihak kepada pendapat siapapun kecuali al-Quran dan Hadits. Untuk mewujudkan sikap netral itu, mufasir dituntut mengosongkan pikirannya dari segala bentuk ajaran dan aliran serta pendapat-pendapat yang akan mengganggunya pada waktu menafsirkan ayat-ayat al-Quran. Artinya dalam proses penafsiran, seseorang mufasir harus membebaskan diri sebebas-bebasnya dari berbagai keterikatan yang akan menghalanginya mencapai petunjuk yang diberikan Allah di dalam ayat yang ditafsirkan. Baidan mengemukakan pendapat al-Mawdûdî yaitu netral adalah kriteria pertama yang harus dimiliki oleh setiap orang yang bermaksud menafsirkan al-Quran. ${ }^{22}$

3. Sadar, Baidan menjelaskan point yang ketiga ini adalah sebagai berikut mufasir harus sadar bahwa yang sedang dikajinya ialah firman Allah yang mengandung mukjizat, yakni suatu kekuatan untuk mengalahkan musuh-musuh yang menentangnya. Kalam Tuhan bersifat universal dan berlaku sepanjang masa. Selain itu gaya bahasa dan sistematika penyusunannya di dalam musḩaf mempunyai cara khusus yang tak ditemui pada kitab-kitab lain yaitu yang diturunkan Allah sebelumnya. Karena itu seorang mufasir harus sadar, memahami dan menghayati dengan baik siapa yang berbicara dengan al-Quran kepada siapa al-Quran itu diturunkan dan siapa yang menjadi sasaran dari ayat-ayat al-Quran yang tengah ditafsirkan $^{23}$

4. Ilmu Mauhibah, ini kreteria terakhir yang di syaratkan Baidan harus menjadi kepribadian seorang mufasir. Kata mawhibah berasal dari bahasa Arab مَوْ هِبَة yang berari "perolehan" atau hibah. Jadi ilmu mawhibah dapat diartikan pengatahuan pemberian atau hiban dari Allah. Akan tetapi apakah Allah akan memberinya tanpa usaha selayaknya hibah. Maka ilmu mawhibah ialah pengetahuan yang di dapat

${ }^{21}$ Baidan, Rekonstruksi, pp. 34-7.

${ }^{22}$ Ibid., pp. 37-42.

${ }^{23}$ Ibid., pp. 42-4. 
setelah bekerja dan berusaha maksimal dalam mengamalkan ilmu yang sudah ada sesuai dengan firman Tuhan di dalam ayat terakhir QS al-Ankabut: 69.

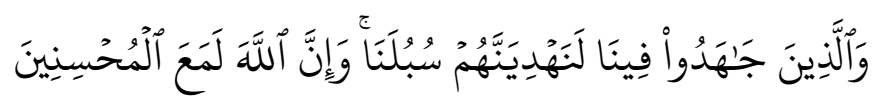

Artinya: "dan orang-orang yang berjihad untuk (mencari keridhaan) Kami, benarbenar akan Kami tunjukkan kepada mereka jalan-jalan kami. Dan Sesungguhnya Allah benar-benar beserta orang-orang yang berbuat baik.'

Dengan demikian ilmu ini dapat disebut Ilmu perolehan, yang merupakan buah dari kerja keras yang terus menerus dalam rangka mengabdi kepada Tuhan. Lafal "Ibadah" (mengabdi) disini adalah kata kunci karena mereka yang rajin beribadah dengan ikhlas, biasanya berakhlak baik seperti sopan, rendah hati, tidak sombong, tidak angkuh, tidak takabur dan sebagainya. Jadi Ilmu mawahibah amat penting bagi orang yang ingin memahami ayat-ayat al-Quran karena yang akan dipahami itu ialah kalam Allah. Sudah tentu dia-lah yang paling tahu tentang isi al-Quran itu. Dengan adanya llmu ini, maka mufasir dapat memahami al-Quran sesuai dengan yang dimaksudkan Allah. Ilmu ini bukanlah di luar jangkauan manusia. Artinya mufasir dapat mengusahakannya dengan cara selalu ber- taqarrub (mendekatkan diri) kepada Allah dengan memperbanyak ibadah dan mensucikan jiwa dari sifat-sifat yang tak terpuji. ${ }^{24}$

M. Quraish Shihah menceritakan dalam bukunya bagaimana para sahabat juga berbeda pendapat dan keliru dalam memahami maksud firman-firman Allah dan bahwa al-Quran mengecam orang-orang yang tidak memperhatikan kandungannya, sehingga dari kalangan mereka sejak dini telah timbul pembatasan-pembatasan dalam penafsiran Al-Quran. Ibn 'Abbas, yang dinilai sebagai salah seorang sahabat Nabi yang paling mengetahui maksud firman-firman Allah, menyatakan bahwa tafsir terdiri dari empat bagian: pertama, yang dapat dimengerti secara umum oleh orang-orang Arab berdasarkan pengetahuan bahasa mereka; kedua, yang tidak ada alasan bagi seseorang untuk tidak mengetahuinya; ketiga, yang tidak diketahui kecuali oleh ulama; dan keempat, yang tidak diketahui kecuali oleh Allah. ${ }^{25}$

${ }^{24}$ Ibid., pp. 44-6.

${ }^{25}$ M. Quraish Shihab, Membumikan al-Quran Fungsi dan Peran Wahyu dalam Kehidupan dan Masyarakat, (Bandung: Mizan, 1992), p. 62. 
Kemudian lebih lajut Quraish mengemukakan dari segi syarat menganai penafsir, khusus bagi penafsiran yang mendalam dan menyeluruh, ditemukan banyak syarat. Secara umum dan pokok dapat disimpulkan sebagai berikut:

1. Pengetahuan tentang bahasa Arab dalam berbagai bidangnya;

2. Pengetahuan tentang ilmu-ilmu Al-Quran, sejarah turunnya, hadis-hadis Nabi, dan ushul fiqh;

3. Pengetahuan tentang prinsip-prinsip pokok keagamaan;

4. Pengetahuan tentang disiplin ilmu yang menjadi materi bahasan ayat. Bagi mereka yang tidak memenuhi syarat-syarat di atas tidak dibenarkan untuk menafsirkan AlQuran. ${ }^{26}$

Syarat-syarat atau kriteria yang diajukan ke empat tokoh dan concern pada ilmu ini yang saya kemukakan di atas memiliki argument yang tepat agar mufasir memperhatikan dengan mendalam secara garis besar pengkategorisasian yang mereka ajukan. Jelas pendapat mereka berbeda akan tetapi tujuan yang diharapkan adalah sama yaitu agar mufasir dalam mentafsirkan al-Quran sesuai dengan kehendak Allah SWT.

\section{Ilmu-Ilmu Bantu dalam menafsirkan Al-Quran}

Selanjutnya saya berpikir bahwa sangat penting untuk mengetahui juga ilmuilmu bantu dalam menafsirkan al-Quran, akhirnya masih mungutif Ghazali dan Gunawan. Mereka bedua mengemukan bahwa terdapat seperangkat ilmu yang harus dikuasai mufasir ketika menafsirkan al-Quran. Ilmu-ilmu tersebut adalah sebagai berikut:

1. Lughhah al-Arobiyah (bahasa Arab). Dengan ilmu ini akan diketahui syarah katakata yang tunggal;

2. Qawaid al-lughah (atauran-atauran bahasa Arab), baik mengenai kata-kata tunggalnya, maupun mengenai tarkib-tarkibnya atau dengan kata lain menguasai ilmu sharaf atau ilmu nahwu;

3. Ilmu ma'ani, bayan dan badie. Dengan ilmu ma'ani akan diketahu rahasia-rahasia susunan pembicaraan dari pembicara. Dengan ilmu bayan diketahui susunan perkataan yang berlainan. Dengan ilmu badie, akan diketahui keindahan pembicaraan;

${ }^{26}$ Ibid., p. 63. 
4. Dapat menentukan yang mubham (samar) dapat menjelaskan yang mujmal (umum), dan dapat mengetahui sebab nuzul dan naskh;

5. Mengetahui ijmal, tabyin, umum, khusus, itlaq, taqyid, petunjuk suruhan, petunjuk larangan dan yang sepertinya;

6. Menguasai ilmu kalam dan ilmu qiraat. ${ }^{27}$

Selanjutnay Ghazali dan Gunawan mengutif M Ali as-Shabuni dalam al-Tibya fi 'Ulu, al-Quran, menyebutkan beberapa persyaratan ilmu yang harus dimiliki (dikuasai) oleh mufasir adalah:

1. Ilmu-ilmu bahasa Arab: mencakup matan al-lughah, nahwu, sharaf dan istiqaq;

2. Ilmu-ilmu balaghah, mencakup maani, bayan dan badie.; Ilmu qiraat

3. Ilmu ushul fiqih;

4. Ilmu ushuluddin;

5. Ilmu asbab ab-nuzul (sebab-sebab diturunkannya al-Quran);

6. Ilmu al-qashah;

7. Ilmu hadits. ${ }^{28}$

Namun pada akhir penjelasannya Ghazali dan Gunawan. Mengemukakan pendapat Rachmat Syafei yang berargumen meskipun semua ilmu tersebut harus dikuasai oleh mufasir, tetapi bukan berarti semua kaidah dalam ilmu-ilmu tersebut diperlukan untuk menafsirkan al-Quran. Mufasir hanya membutuhkan kaidah-kaidah yang tidak diketahui kemudian dipedomi dalam menafsirkan al-Quran. ${ }^{29}$

\section{Faktor-Faktor Penyebab Penyimpangan dalam Penafsiran Al-Quran}

Quraish menekankan bahwa syarat-syarat seorang mufasir sangat penting. Sebagaimana yang penulis kemukakan di atas. Menurut Quraish bagi mereka yaitu mufsir yang tidak memenuhi syarat-syarat tersebut tidak dibenarkan untuk menafsirkan Al-Quran. ${ }^{30}$ Quraish berargument menurutnya ada dua hal yang perlu digarisbawahi:

1. Menafsirkan berbeda dengan berdakwah atau berceramah berkaitan dengan tafsir ayat Al-Quran. Seseorang yang tidak memenuhi syarat-syarat di atas, tidak berarti terlarang untuk menyampaikan uraian tafsir, selama uraian yang dikemukakannya

${ }^{27}$ Ghazali dan Gunawan, Studi Islam Suatu, p. 121.

${ }^{28}$ Ibid.

${ }^{29}$ Ibid.

${ }^{30}$ M. Quraish Shihab, Membumikan, p. 63. 
berdasarkan pemahaman para ahli tafsir yang telah memenuhi syarat di atas. Seorang mahasiswa yang membaca kitab tafsir semacam Tafsir An-Nur karya Prof. Hasby As-Shiddiqie, atau Al-Azhar karya Hamka, kemudian berdiri menyampaikan kesimpulan tentang apa yang dibacanya, tidaklah berfungsi menafsirkan ayat. Dengan demikian, syarat yang dimaksud di atas tidak harus dipenuhinya. Tetapi, apabila ia berdiri untuk mengemukakan pendapat-pendapatnya dalam bidang tafsir, maka apa yang dilakukannya tidak dapat direstui, karena besar kemungkinan ia akan terjerumus ke dalam kesalahan-kesalahan yang menyesatkan. ${ }^{31}$

2. Faktor-faktor yang mengakibatkan kekeliruan dalam penafsiran antara lain adalah:

a. Subjektivitas mufasir;

b. Kekeliruan dalam menerapkan metode atau kaidah;

c. Kedangkalan dalam ilmu-ilmu alat;

d. Kedangkalan pengetahuan tentang materi uraian (pembicaraan) ayat;

e. Tidak memperhatikan konteks, baik asbab al-nuzul, hubungan antar ayat, maupun kondisi sosial masyarakat. Tidak memperhatikan siapa pembicara dan terhadap siapa pembicaraan ditujukan. ${ }^{32}$

Hampir sama dengan apa yang dikemukakan Quraish, Rachmat Syafei yang dikutip Ghazali dan Gunawan, Syafei menyebutkan secara umum terdapat beberapa kesalahan atau kekeliruan dalam menafsirkan Al-Quran. Di antaranya oleh hal-hal berikut:

1. Mufasir menyalahi beberapa persyaratan sebagaimana telah disebutkan di atas. Misalnya, seorang mufasir tidak mengetahui nasikh mansukh, tidak menguasai bahasa Arab dan ilmu lainnya;

2. Seorang mufasir berbicara tentang suatu masalah, tetapi ia sendiri tidak mengerti masalah tersebut. Misalnya, ketika menafsirkan ayat "kaanan Naasu Ummatan Waadidatan" ayat ini sangat berkaitan dengan masalah sosiologi. Dengan demikian, penafsirannya tidak cukup dengan satu pendekatan saja, tetapi dilakukan dengan berbagai macam pendekatan (multi approach), dan tidak mungkin dilakukan dengan seorang mufasir saja;

3. Adanya unsure subjektivitas dari orang yang menafsirkan al-Quran;

${ }^{31}$ Ibid., pp. 63-4.

${ }^{32}$ Ibid., p. 64. 
4. Kesalahan dalam metode pendektan (al-Khata fi al-Manhaj), ini diakui oleh Ibn Rusyd bahwa ada masalah dalam al-Quran yang didekati oleh pendekatan yang tidak pada tempatnya;

5. Kesalahan dalam melihat mutakalim (yang berbicara) dan mukhatab (yang diajak bicara).$^{33}$

Lebih lanjut Ghazali dan Gunawan menjelaskan pangkal kesalahan biasanya terletak pada pemahaman lafadz atau kalam hal tersebut memiliki dua bentuk seperti berikut:

1. Menafsrikan makna dari pengertian-pengertian di mana lafadz-lafadz al-Quran itu dibawanya pada pengertian yang sesuai dengan keyakinannya;

2. Penafsiran al-Quran semata-mata menurut bahasa (orang Arab) tanpa memerhatikan pembicaraan al-Quran yang kepadanya al-Quran itu diturunkan, serta berbicara kepadanya dengan memakai al-Quran itu juga. ${ }^{34}$

Baidan secara tersirat menjelaskan dalam bukunya mengenai faktor-faktor penyebab terjadi kesalahan dalam penafsiran al-Quran. Baidan berargumen hal ini disebabkan kepribadian mufasir, sehingga sikap subjektif terjadi. Sebagaimana yang saya kemukakan menganai pendapat Baidan menganai kepribadian mufasir ada empat, maka Baidan mengemukakan bahwa penyebab kesalahan dalam penafsiran adalah antonim dari keempat hal tersebut.

Pertama, yaitu orang yang tidak ikhlas dalam beramal, maka itu artinya mencari keuntungan pribadi atau golongan ataupun yang lain, sikap seperti ini jelas akan menghasilkan penafsiran yang tendensius merusak tatanan yang sudah baik atau malah menimbulkan kegaduhan ditengah masyarakat. Baidan menegaskan terjadinya berbagai penyimpangan dalam penafsiran berawal dari tidak adanya keikhlasan dan ketulusan seseorang dalam penafsiran. ${ }^{35}$

Kedua, Kuatnya pengaruh aliran yang mendominasi pemikiran mufasir sehingga ia senantiasa berusaha mengerahkan seluruh kemampuan dan daya pikirnya dalam menafsirkan ayat al-Quran supaya cocok dengan paham yang dianutnya. Dalam ungkapan lain, para penganut suatu aliran tertentu cenderung berupaya menundukkan al-Quran dibawah pemikiran mereka; bukan sebaliknya. Dari itu kelompok seperti ini

33 Ghazali dan Gunawan, Studi Islam Suatu, p. 121.

${ }^{34}$ Ibid., pp. 121-2.

${ }^{35}$ Nashruddin Baidan, Rekonstruksi, pp. 37-38. 
tidak segan-segan memanipulasi makna yang dikandung oleh suatu ayat, bahkan tanpa malu sedikitpun mereka memberikan makna atas suatu ayat berdasarkan aliran yang dianut oleh mereka. ${ }^{36}$

Ketiga, Mufasir tidak tidak sadar bahwa yang dikajinya adalah firman Allah, bahkan menyamakannya dengan kalam manusia. Jika kondisi ini terjadi maka kemungkinan keliru dalam memahami dan menafsirkan al-Quran semakin besar. ${ }^{37}$ dan Keempat, Baidan berargument dengan berlandaskan QS. al-A'raf ayat 146, sebagai berikut:

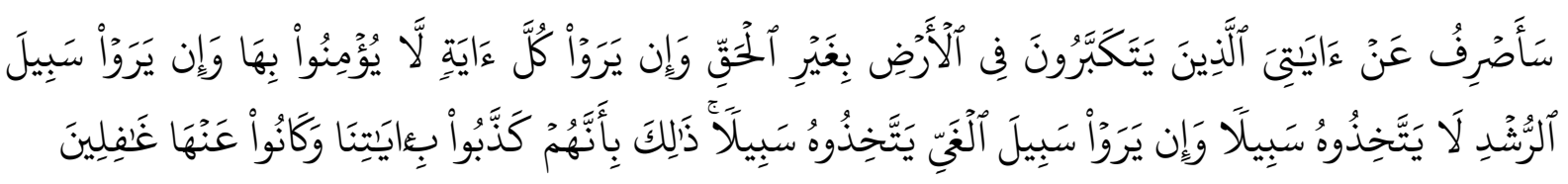

Artinya: "Aku akan memalingkan orang-orang yang menyombongkan dirinya di muka bumi tanpa alasan yang benar dari tanda-tanda kekuasaan-Ku. mereka jika melihat tiaptiap ayat $(\mathrm{Ku})^{38}$, mereka tidak beriman kepadanya dan jika mereka melihat jalan yang membawa kepada petunjuk, mereka tidak mau menempuhnya, tetapi jika mereka melihat jalan kesesatan, mereka terus menempuhnya, yang demikian itu adalah karena mereka mendustakan ayat-ayat kami dan mereka selalu lalai dari padanya."

Baidan menjelakan maksud ayat ini kata Sufyan bin 'Uyaynat: "Tuhan mencabut pemahaman al-Quran dari mereka yang sombong itu". Apakah ciri ciri orang yang takabur atau sembong dalam lanjutan ayat ini Tuhan menerangkan ciri-ciri mereka sebagai berikut:

1. Tidak percaya kepada ayat-ayat Allah

2. Mereka tahu jalan yang benar tapi masih menempuh jalan yang sesat

3. Disamping mendustakan ayat-ayat Allah, mereka tak mempercayai akhirat. ${ }^{39}$

\section{E. Pentafsiran al-Quran memuat kepentingan}

\section{Pentafsiran al-Quran bermuatan kepentingan: sederhana}

Baidan menunjukan kesalahan penafsiran al-Quran pada masa awal ilmu tafsir al-Quran ada. Contoh yang diberikannya penafsiran kaum Râfidhah $^{40}$ dalam

\footnotetext{
${ }^{36}$ Ibid., p. 42.

${ }^{37}$ Ibid., pp. 43-44.

38 Yang dimaksud dengan ayat-ayat di sini ialah: ayat-ayat Taurat, tanda-tanda kebesaran dan

${ }^{39}$ Nashruddin Baidan, Rekonstruksi, p. 46

40 Adapun rafidhah secara bahasa bermakna meninggalkan. Adapun secara istilah rafidhah
} kekuasaan Allah. adalah suatu aliran yang menisbatkan dirinya kepada syiah (pengikut) ahlul bait, namun mereka berlepas 
menafsirkan بَدًَا آَبِى لَهَب yang terdapat dalam ayat pertama dari QS. al-Lahab dengan abu bakar dan umar sehingga pengertian nya menjadi "celakalah Abu Bakar dan Umar sebenar-benar celaka"

Artinya: "Binasalah kedua tangan Abu Lahab dan Sesungguhnya Dia akan binasa."11

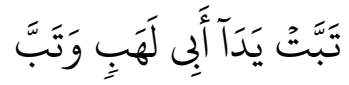

Contoh di atas menunjukkan ketidaksukaan kaum Râfidhah kepada kedua Khalifah ini. Sebagian ulama menyatakan bahwa sebab penamaan Râfidhah adalah karena mereka meninggalkan dan menolak (rofadho) kepemimpinan (imaamah) Abu Bakar dan Umar. Dengan meyakini bahwa kepemimpinan yang seharusnya sepeninggal Nabi Muhammad adalah ditangan Ali bin Abi Thalib Radhiyallahu'Anhum. Namun mayoritas ulama menyatakan bahwa penamaan Râfidhah bermula pada masa Zaid bin Ali Rahimahullah. Yang mana ketika itu beliau meyakini bahwa Ali lebih utama dibandingkan Utsman. Beliaupun masih memberikan loyalitasnya kepada Abu Bakar dan Umar dan menganggap mereka sebagai manusia terbaik sepeninggal Nabi Muhammad 㗪. Namun ternyata diantara pengikutnya yang telah berbaiat kepadanya ada sebagian orang yang justru mencela Abu bakar dan Umar. Maka Zaid pun langsung menegur dan mengingkari mereka, hingga akhirnya mereka berpecah belah dan meninggalkan Zaid bin Ali. Maka Zaid pun berkata kepada mereka, "kalian telah meninggalkanku" (rofadhtumuunii), maka sejak saat itulah mereka dikenal dengan nama Rafidhah. ${ }^{42}$

Contoh lain yang dikemukakan Baidan adalah mengenai kata بَََََرَة di dalam ayat 67 dari al-Baqarah:

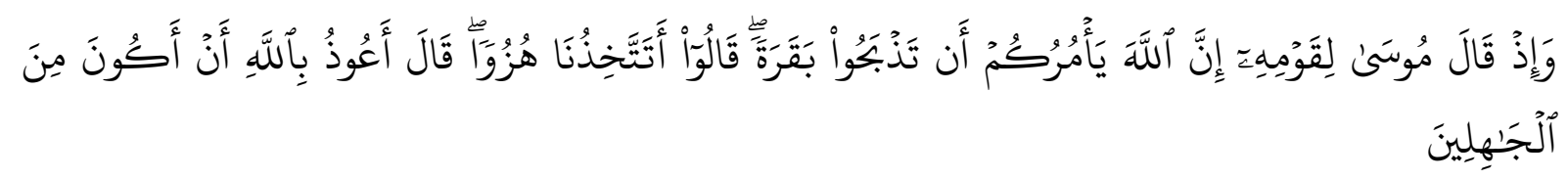

Mereka menafsirkan dengan "Aisyah, sehingga ayat itu berkonotasi "sesungguhnya Allah memerintahkan kamu menyembelih Aisyah". Penafsiran ini

diri (baro') dari Abu Bakar dan Umar bin Khathab. Lihat, Sumber: https://muslim.or.id/25664-mengenalsyiah-antara-syiah-dan-rafidhah.html.

${ }^{41}$ Yang dimaksud dengan kedua tangan Abu Lahab ialah Abu Lahab sendiri

42 Muhammad Singgih Pamungkas, Mengenal Syiah anatara Syiah dan Rafidhah, dalam https://muslim.or.id/ 25664-mengenal-syiah-antara-syiah-dan-rafidhah.html, 31 Mei 2015. 
dilakukan oleh Syi'ah al-Islamiyah yang dikenal dengan kaum batiniyah ${ }^{43}$. Dalam sebuah artikel Muslim.or.id dijelaskan bahwa ini adalah bentuk Syi'ah untuk menjatuhkan Islam adalah dengan mencela dan menghina Ummul Mukminin, 'Aisyah. Karena dengan mencelanya, hilanglah seperempat syariat Islam yang dibawanya, sebagaimana yang disebutkan oleh Al-Hakim Abu Abdillah berkata, "Diriwayatkan dari 'Aisyah radhiyallahu 'anha seperempat syariat". Maka semua hadits yang diriwayatkannya akan tertolak dan tidak akan dijadikan pedoman dalam syariat Islam. ${ }^{44}$

\section{Pentafsiran Ayat al-Quran Berbeda Kepentingan: Kompleks}

Lebih komplek dari yang dicontohkan Baidan, Gusmian memaparkan dengan bahasanya yang menarik "diskursus dalam teologi Islam klasik". Gusmian menjelaskan tentang perbedaan pandangan para mufasir terhadap beberapa hal salah satunya keterciptaan perempuan. Saya mengambil contoh ini karena begitu kompleknya kepentingan dan kekuatan kepercayaan pada diri si Mufasir bahwa ia dalam mentafsirkan ayat al-Quran sudah benar sesuai dengan yang di maksud Tuhan. Pada awal penjelasannya Gusmian menekankan pentingnya melihat pandangan al-Quran tentang asal kejadiannya. Menurut Gusmian inilah sebab dan dari arah inilah klaimklaim, baik yang bernada positif dan atau negatif, tentang perempuan muncul.

Mengawali penjelasannya Gusmian menjelaskan bahwa kronologis asal-usul kejadian manusia tidak dijelaskan oleh al-Quran. Cerita penciptaan manusia, banyak diketahui melalui hadits, kisah isra'iliyyat, dan riwayat yang bersumber dari kitab Taurat, Injil dan Talmud. ${ }^{45}$ Substansi asal-usul kejadian Adam dan Hawa juga tidak

${ }^{43}$ Syi'ah Ali adalah Pendukung Ali r.a., Syi'ah Mu'awiyah adalah pendukung Mu'awiyah r.a. Namun baik Syi'ah Ali maupun Syi'ah Muawiyah di masa itu keduanya Ahlus Sunnah wal Jama'ah, karena aqidah dan fahamnya sama, Al-Qur'an dan As-Sunnah. Namun setelahnya Syi'ah kemudian berkembang dari aliran politik menjadi aliran aqidah dan fiqh baru. Sumber rujukan Syi'ah yang utama dan induk ada 4 Kitab (Al-Kutub al-Arba'ah). Syi'ah kemudian berpecah menjadi banyak firqah: Syi'ah 7, Syi'ah 12, Syi'ah 12 Ja'far, Hasyimiyah, Hamziyah, Manshuriyah, Mughiriyah, Harbiyah, Khatthabiyah, Ma'mariyah, Bazighiyah, Sa'idiyah, Basyiriyah, 'Albaiyah, Hisyamiyah, Ruzamiyah, Nu'maniyah, Musailamiyah, Isma'iliyah, Waqifiyah, Mufawwidhah, Ghurabiyah, Kamiliyah, Nushairiyah, Ishaqiyah. Syi'ah yang berkembang pesat hari ini adalah Meyakini bahwa kepemimpinan ada pada 12 Imam. Lihat, Yusnatali, Nasihat dan kajian: Siaapakah Syiah, dalam http://yusnatali.dosen.akademitelkom.ac.id/ index.php/ nasihat-dan-kajian/siapakah-syiah/, 24 September 2017.

${ }^{44}$ Rian Permana, Syiah Mencela Umul Mukmin, Aisah, dalam, https://muslim.or.id/8759-syiahmencela-ummul-mukminin-aisyah.html, 25 Maret 2015.

45 Talmud adalah catatan tentang diskusi para Rabi yang berkaitan dengan hukum Yahudi, etika, kebiasaan dan sejarah. Talmud mempunyai dua komponen: Mishnah dan Gemara. Mishnah merupakan kumpulan Hukum Lisan Yudaisme pertama yang ditulis. Gemara atau Talmud adalah dasar dari semua aturan dari hukum rabinik dan banyak dikutip dalam literatur rabinik yang lain. Lihat Open Dictionary Wikipedia, https://id.wikipedia.org/wiki/Talmud 
dibedakan secara tegas. Memang ada isyarat bahwa Adam diciptakan dari tanah kemudian dari tulang rusuk Adam ini diciptakan Hawa. Namun isyarat ini diperoleh dari Hadits. Kata Hawa yang selama ini dipersepsikan sebagai perempuan yang menjadi istri Adam, sama sekali tidak pernah disinggung dalam al-Quran. Bahkan, klaim bahwa Adam sebagai manusia pertama dan berjenis kelamin laki-laki masih dipertanyakan oleh beberapa kalangan. ${ }^{46}$ Rasulullah bersabda,

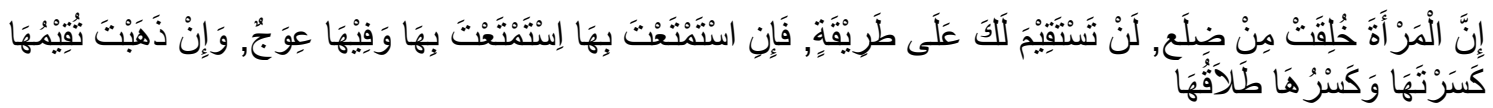

Artinya: "Sesungguhnya wanita diciptakan dari tulang rusuk, ia tidak bisa lurus untukmu di atas satu jalan. Bila engkau ingin bernikmat-nikmat dengannya maka engkau bisa bernikmat-nikmat dengannya namun padanya ada kebengkokan. Jika engkau memaksa untuk meluruskannya, engkau akan memecahkannya. Dan pecahnya adalah talaknya." (HR. Muslim)

Lebih lanjut Gusmian memaparkan bahwa satu-satunya ayat yang mengisyaratkan soal ini adalah QS. al-Nisa (4): 1 kata kunci yang menjadi sumber analisis dalam ayat ini -yang kemudian melahirkan perdebatan- adalah kalimat (1) nafs wâhidah (diri yang satu), (2) objek yang ditunjuk dengan kata ganti: minhâ (darinya), dan (3) apa yang dimaksudkan dengan kata: zawjahâ (pasangan). ${ }^{47}$

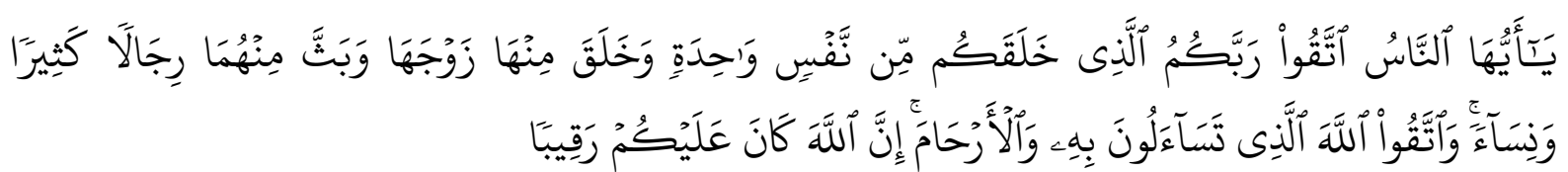

Terjemahnya:

"Hai sekalian manusia, bertakwalah kepada Tuhan-mu yang telah menciptakan kamu dari seorang diri, dan dari padanya ${ }^{48}$ Allah menciptakan isterinya; dan dari pada keduanya Allah memperkembang biakkan laki-laki dan perempuan yang banyak. dan bertakwalah kepada Allah yang dengan (mempergunakan) nama-Nya kamu saling meminta satu sama lain ${ }^{49}$, dan (peliharalah) hubungan silaturrahim. Sesungguhnya Allah selalu menjaga dan mengawasi kamu."

46 Gusmian, Khazanah Tafsir, p. 331; dan Nasaruddin Umar, Misteri Nafs al-Wahidah, https://paramadina.wordpress.com/2007/03/16/misteri-nafs-al-wahidah/, 16 Maret 2007.

${ }^{47}$ Gusmian, Khazanah Tafsir, pp. 331-2.

48 Maksudnya menurut Jumhur mufassirin ialah dari bagian tubuh (tulang rusuk) Adam a.s. berdasarkan hadis riwayat Bukhari dan Muslim. di samping itu ada pula yang menafsirkan dari padanya ialah dari unsur yang serupa Yakni tanah yang dari padanya Adam a.s. diciptakan.

${ }^{49}$ Menurut kebiasaan orang Arab, apabila mereka menanyakan sesuatu atau memintanya kepada orang lain mereka mengucapkan nama Allah seperti: Asaluka billah artinya saya bertanya atau meminta kepadamu dengan nama Allah. 
Para Mufasir, setidaknya terpecah dalam dua pemahaman kelompok pertama, seperti dapat dilihat dalam Tafsir al-Qurthibî, Tafsir ibn Katsîr, Tafsir Rûh al-Bayân, Tafsir al-Kasysyâf, Tafsir al-Jâmi' al-Bayân, dan tafsir al-Marâghî, menafsirkan kata: nafs wâhidah dengan "Adam", kata ganti: minhâ dengan "dari bagian tubuh "Adam" dan kata zawjahâ dengan "Hawa". Alasan mereka adalah karena adanya hadits yang mengisyaratkan bahwa perempuan (Hawa) diciptakan dari Adam. ${ }^{50}$

Kelompok kedua, memahami asal-usul kejadian perempuan bukan dari tulang rusuk Adam, tepi dari jenis (jins) Adam. Al-Râzî termasuk dalam kelompok ini. Dengan mengutip pendapat Abû Muslim al-Ishfâhânî, dia mengatakan bahwa kata ganti: hâ, pada kata: minhâ dalam ayat di atas, bukan bagian tubuh Adam, tetapi dari jenis Adam. Dia membandingkan pendapatnya ini dengan menganalisis kata nafs yang digunakan dalam QS. al-Nahl (16): (78), Ălu 'imrân (3): 164 dan al-Tawbah (9): 128. ${ }^{51}$

QS. al-Nahl (16): (78)

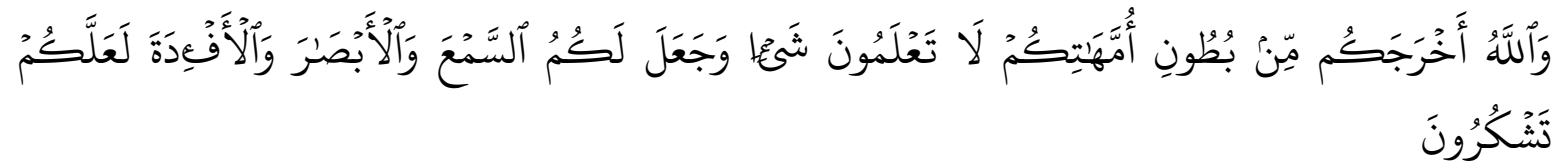

Artinya: "dan Allah mengeluarkan kamu dari perut ibumu dalam Keadaan tidak mengetahui sesuatupun, dan Dia memberi kamu pendengaran, penglihatan dan hati, agar kamu bersyukur."

QS. Älu 'imrân (3): 164

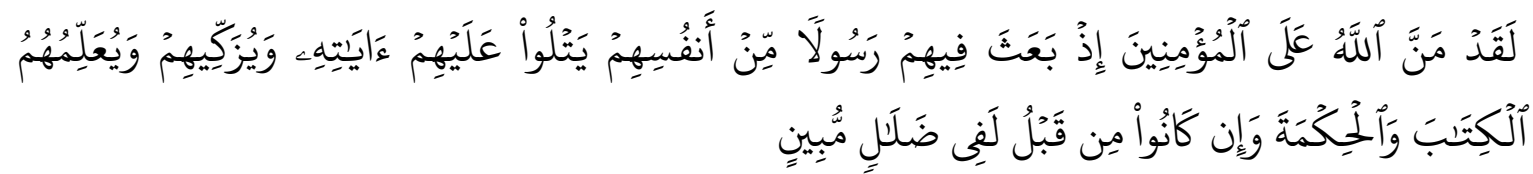

Artinya: "sungguh Allah telah memberi karunia kepada orang-orang yang beriman ketika Allah mengutus diantara mereka seorang Rasul dari golongan mereka sendiri, yang membacakan kepada mereka ayat-ayat Allah, membersihkan (jiwa) mereka, dan mengajarkan kepada mereka Al kitab dan Al hikmah. dan Sesungguhnya sebelum (kedatangan Nabi) itu, mereka adalah benar-benar dalam kesesatan yang nyata." QS. al-Tawbah (9): 128.

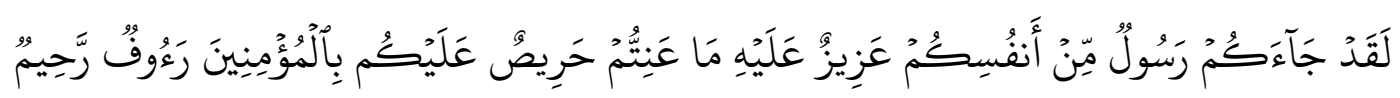

Artinya: "sungguh telah datang kepadamu seorang Rasul dari kaummu sendiri, berat terasa olehnya penderitaanmu, sangat menginginkan (keimanan dan keselamatan) bagimu, Amat belas kasihan lagi Penyayang terhadap orang-orang mukmin."

50 Gusmian, Khazanah Tafsir, p. 332.

51 Ibid. 
Gusmian mengemukakan bahwa 'Abduh, termasuk dalam kelompok kedua, dalam Tafsir al-Manâr ${ }^{52}$, mengemukakan beberapa alasan. Pertama, ayat itu diawali kata yâ ayyuha al-nâs (wahai sekalian manusia). Ini berarti ditujukan kepada seluruh manusia. Bagaimana mungkin itu dikatakan Adam, sementara Adam tidak popular dan tidak diakui keberadaaanya oleh semua umat manusia sebagai manusia pertama. Oleh karena itu menurutnya, pengertian min nafs wâhidah dalam ayat ini, mestinya yang dapat diakui secara universal. ${ }^{53}$ Kedua, bila memang yang dimaksud adalah Adam, mengapa menggunakan bentuk nakirah pada kata rijâl, bukan bentuk ma'rifah: al-rijâl wa al-nisâ'. Dengan mengutip pendapat para filosof, 'Abduh lalu menganggap kata nafs mempunyai arti yang sama dengan kata rûh, yaitu suatu yang bersifat non-materi. Ini artinya nafs tidak bisa diartikan Adam yang berkonotasi materi. ${ }^{54}$

Terus bagaimana di Indonesia, Gusmian menjelaskan bahwa dua pendapat di atas, mewarnai karya tafsir Indonesia. Tafsir kebencian ${ }^{55}$ dan Argument kesetaraan Gender Karya Nasaruddin Umar termasuk yang sangat tegas menolak pendapat pertama. Dengan mengutip Riffat $\operatorname{Hasan}^{56}$ dan Fatima Mernissi, Zaitunah Subhan

52 Tafsir al-Manar yang bernama Tafsir al-Qur'an al-Haki memperkenalkan dirinya sebagai "kitab tafsir satu-satunya yang menghimpun riwayat-riwayat yang shahih dan pandangan akal yang tegas, yang menjelaskan hikmah-hikmah syariah serta sunnatullah terhadap manusia, dan menjelaskan fungsi alQuran sebagai petunjuk untuk seluruh manusia, disetiap waktu dan tempat, serta membandingkan antara petunjuknya dengan keadaan kaum Muslim dewasa ini (pada masa diterbitkannya) yang telah berpaling dari petunjuk itu." Tafsir ini disusun dengan redaksi yang mudah sambil berusaha menghindari istilahistilah ilmu dan teknis sehingga dapat dimengerti oleh orang awam, tetapi tidak dapat diabaikan oleh cendikiawan. Penulisan tafsir ini dilatar belakangi oleh situasi kondisi sosial, politik, dan budaya yang sangat memprihatinkan, tidak hanya di Mesir tapi juga di hampir seluruh Negara Arab. Persoalan ini membuat M. Abduh merasa perlu melakukan pembaharuan pemikiran masyarakat Islam akan hal tersebut. Ridha Basri, Studi Kitab Tafsir al-Manar Karya Muhammad Abduh dan Muhammad Rasyid Ridha, https://ridhabasri.wordpress.com/2016/08/18/studi-kitab-tafsir-al-manar-karya-muhammad-abduhdan-muhammad-rasyid-ridha/, 18 Agustus 2016.

53 Gusmian, Khazanah Tafsir, pp. 332-3.

${ }^{54}$ Ibid., p. 333.

55 Zaitunah Subhan, Sebagai seorang wanita karier, beliau tidak hanya aktif sebagai dosen, melainkan juga aktif dalam berorganisasi. Manhaj Tafsir Kebencian karya Zaitunah menggunakan metode tafsîr bi al-ra'yî. Tharîqah Tafsir Kebencian Karya Zaitunah menggunakan metode muqâran (komparatif). Setelah memaparkan seluruh pendapat yang ada dan menganalisisnya, Zaitunah, mengemukakan pandangannya melalui beberapa perbandingan. Tafsir karya Zaitunah ini tidak dapat dinilai sebagai memiliki kecenderungan kepada madzhab atau aliran tertentu baik aliran kalam maupun aliran Fiqh. Dalam konteks keindonesiaan, Tafsir Kebencian karya Zaitunah dengan tegas merepresentasikan kecenderungan pada tafsir-tafsir yang berupaya memposisikan "pembacaan" ayat-ayat dalam relasi gender secara seimbang dan setara. Ide-ide yang dikemukakan Zaitunah dalam Tafsir Kebencian-nya sejalan dengan ide-ide yang telah dilontarkan feminis muslim. Norhidayat, Tafsir Kebencian, http://chaqoqo.blogspot.co.id/2011/11/tafsir-kebencian-karya-zaitunah-subhan.html Oleh: Alumni UIN Jakarta Selasa, 22 November 2011.

56 Riffat Hassan, lahir 1943, adalah seorang teolog Pakistan-Amerika dan seorang ilmuwan feminis Islam terkemuka dari Al-Qur'an. Teologi Hassan adalah contoh dari Progressive 
mengklaim bahwa pendapat kedua adalah yang rasional. Alasan dia, kata Adam dalam istilah bahasa Ibrani berarti tanah -berasal dari kata adamah- sebagian besar berfungsi sebagai istilah generik untuk manusia, bukan menyangkut jenis kelamin. Memperkuat pendapatnya ini, dia lalu mengutip QS. al-Isrâ (17): 70 dan al-Tîn (95): 4

QS. al-Isrâ (17): 70

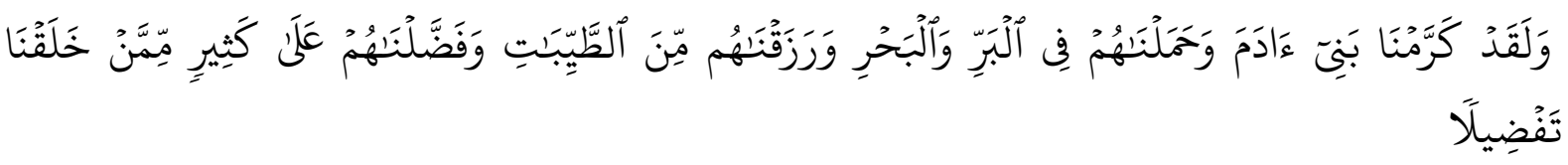

Artinya: "dan Sesungguhnya telah Kami muliakan anak-anak Adam, Kami angkut mereka di daratan dan di lautan ${ }^{57}$, Kami beri mereka rezki dari yang baik-baik dan Kami lebihkan mereka dengan kelebihan yang sempurna atas kebanyakan makhluk yang telah Kami ciptakan."

QS. al-Tîn (95): 4

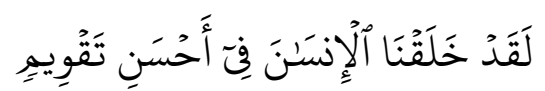

Artinya: "Sesungguhnya Kami telah menciptakan manusia dalam bentuk yang sebaikbaiknya."

Maka itu artinya, secara tidak langsung, Zaitunah menolak pandangan bahwa perempuan (Hawa) diciptakan dari tulang rusuk Adam. ${ }^{58}$

Kemudian Gusmian mencermati pemikiran Nasaruddin dan menurutnya Nasaruddin dalam berargument mengenai kesetaraaan gender lebih kritis karena, Nasaruddin menjelaskan analisisnya menggunakan analisis linguistik. ${ }^{59}$ Nasaruddin menjelaskan bahwa kata nafs, yang terulang 295 kali dalam al-Quran, dengan berbagai bentuknya, tidak satu pun yang dengan tegas menunjuk kepada pengertian Adam. Kata

Islam . Dia mengatakan bahwa Alquran adalah " Magna Carta hak asasi manusia", yang menentukan hak asasi manusia dan persamaan untuk semua orang, sementara ketidaksetaraan perempuan di banyak masyarakat Muslim saat ini disebabkan oleh efek budaya. Hassan mengklaim bahwa Alquran menjunjung tinggi hak atas kehidupan, rasa hormat, keadilan, kebebasan, pengetahuan, rezeki, pekerjaan, dan privasi, antara lain. Dia mendukung interpretasi Qur'an yang tidak kaku, dengan alasan bahwa meskipun itu adalah firman Tuhan, kata-kata dapat memiliki arti yang berbeda, sehingga secara teoritis ada kemungkinan makna Alquran yang tak terhitung jumlahnya. Dia percaya arti Alquran harus ditentukan melalui hermeneutika - pemeriksaan apa arti kata-katanya pada saat ditulis. Dia juga berbicara tentang "kriteria etis" yang menolak penggunaan Alquran untuk melakukan ketidakadilan, karena Tuhan Islam itu adil. Hassan bukan hanya seorang sarjana, dia juga seorang aktivis. Dalam kapasitasnya sebagai aktivis, Hassan mengembangkan dan mengarahkan "Kehidupan Islam di AS" (20022006) dan "Religion and Society: A Dialogue" (2006-2009), dua program pembangunan perdamaian yang menciptakan standar untuk diskusi antaragama. dan pembangunan perdamaian, menyusul serangan tahun 2001. Lihat, Dicyionary Wikipedia, https://en.wikipedia.org/wiki/Riffat_Hassan dan Lihat, Liputan Islam, Kajian Islam Tafsir Wacana Tafsir Indonesia Perempuan tercipta dari Tulang Rusuk Laki-Laki, dalam http://liputanislam.com/kajian-islam/tafsir/wacana-tafsir-indonesia-perempuan-tercipta-daritulang-rusuk-laki-laki2/.

57 Maksudnya: Allah memudahkan bagi anak Adam pengangkutan-pengangkutan di daratan dan di lautan untuk memperoleh penghidupan.

${ }^{58}$ Gusmian, Khazanah Tafsir, p. 333.

${ }^{59}$ Ibid., pp. 333-4. 
nafs, dalam al-Quran kadang berarti jiwa QS. al-Ma'idah (5); 32, nafsu, QS. al-Fajr (89); 27, nyawa/ roh, QS. al-'Ankabût (29): 57, dan asal-usul binatang pada QS. Syûrâ (42):11. Kalau dikatakan al-nafs al-wahidah ialah Adam, berarti Adam juga menjadi asal-usul kejadian hewan dan tumbuh-tumbuhan. ${ }^{60}$

Analisis macam ini juga dipakai Baidan dalam Tafsir bi al-Ra'yi. Dengan bahasa yang lugas, di ujung analisisnya, dia menyimpulkan bahwa wanita menurut al-Quran bukan diciptakan dari tulang rusuk Adam. Melainkan dari unsur yang sama dengan Adam yaitu tanah. ${ }^{61}$

Alasan kedua yang diberikan Nasaruddin Umar adalah bahwa kata nafs wâhidah dalam konteks ayat di atas memakai bentuk nakirah/indefinite, bukan bentuk ma'rifah yang menunjukkan kekhususan, dan diperkuat lagi dengan kata wâhidah. Semua ini lanjut Nasaruddin, menunjukkan pada substansi utama (the first resource), yakni asal (unsur) kejadian Adam, bukan Adam-nya sendiri sebagai substansi kedua. ${ }^{62}$

Kemudian Gusmian menjelaskan pandangan Quraish. Gusmian berargumen Quraish tidak tegas menjelaskan dalam Tafsir al-Mishbah menganai tafsir ayat pertama QS. al-Nisâ (4): 1. ${ }^{63}$ Berikut pentafsiran Quraish yang dikutif Gusmian:

Ayat al-Hujurât memang berbicara tentang asal kejadian manusia yang sama dari seorang ayah dan ibu, yakni sperma ayah dan ovum/indung telur. Tetapi, tekananya pada persamaan hakikat kemanusiann orang perorang, karena setiap orang walau berbeda-beda ayah dan ibunya, tetapi, tekananya pada persamaan hakikat kemunusian orang perorang, karena setiap orang walau berbeda-beda ayah dan ibunya, tetapi unsur dan proses kejadian mereka sama. Adapun ayat al-Nisa ini, maka walaupun ia menjelaskan banyak dan berkembangbiaknnya mereka dari seorang ayah, yakni Adam, dan seorang ibu, yakni Hawa. Ini dipahami dari pernyataan: Allah memperkembangbiakkan laki-laki yang banyak dan perempuan. Ini tentunya baru sesuai jika kata nafs wâhidah dipahami dalam arti ayah manusia seluruhnya (Adam) dan pasangannya (Hawa) lahir dari laki-laki dan perempuan yang banyak. ${ }^{64}$

Kemudian Gusmian menegaskan kembali pandangannya bahwa Quraish cenderung memaknai kata nafs wâhidah dalam artinya ayah manusia seluruhnya, yakni Adam dan pasangannya Hawa. Sebab, dari situlah perkembangbiakannya itu dia

\footnotetext{
${ }^{60}$ Nasaruddin Umar, Misteri Nafs al-Wahidah, dalam https://paramadina.wordpress.com/ 2007/03/16/misteri-nafs-al-wahidah/, diakses 16 Maret 2007.

${ }^{61}$ Liputan Islam, Kajian Islam Tafsir Wacana Tafsir Indonesia Perempuan tercipta dari Tulang Rusuk Laki-Laki, dalam, http://liputanislam.com/kajian-islam/tafsir/wacana-tafsir-indonesiaperempuan-tercipta-dari-tulang-rusuk-laki-laki2/.

62 Gusmian, Khazanah Tafsir, p. 334 dan Nasaruddin Umar, Misteri Nafs al-Wahidah, dalam https://paramadina.wordpress.com/2007/03/16/misteri-nafs-al-wahidah/, diakses 16 Maret 2007.

63 Ibid., p. 333.

${ }^{64}$ Ibid., pp. 334-5.
} 
dasarkan pada kesesuaian makna dalam konteks wacana yang dibicarakan di dalam ayat tersebut. Bahkan ia, memandang paham soal asal-usul kejadian perempuan dari tulang rusuk Adam ini bukan sebagian sebab yang sering melahirkann bias gender. Ketika mengutip kritik Rasyid Ridla atas ide keterciptaan Hawa dari tulang rusuk Adam yang dikalim sebagai pengaruh dari perjanjian lama (kejadian II: 21-22), Masih mengutif Tafsir al-Misbah Gusmian mengemukakan lebih lanjut Quraish menulis: ${ }^{65}$

Perlu dicatat sekali lagi bahwa pasangan Adam itu diciptakan dari tulung rusuk Adam, maka itu bukan berarti bahwa kedudukan wanita-wanita selain Hawa demikian juga, atau lebih rendah dibanding dengan laki-laki. Ini karena semua pria dan wanita anak cucu Adam lahir dari gabungan antara pria dan wanita, sebagaimana penegasan-Nya "sebagian kamu dari sebagaian yang lain" bunyi surat al-Hujurat di atas, dan sebagaimana penegian yang lain" (QS. ali Imran (3): 195. Laki-laki lahir dari pasangan pria dan wanita, begitu juga wanita. Karena itu tidak ada perbedaan dari segi kemanusiaan antara keduanya. Kekuatan laki-laki dibutuhkan oleh wanita dan kelemah lembutan wanita didambakan oleh pria. Jarum harus lebih kuat dari kain, dan kain harus lebih lembut dari jarum. Kalau tidak jarum tidak akan berfungsi, dan kain pun tidak akan terjahit. Dengan berpasangan akan tercipta pakaian indah, serasi dan nyaman. ${ }^{66}$

Berbeda dengan Quraish dalam tafsir al-Mishbah yang kurang tegas dalam berpendapat di atas. Al-Quran dan tafsirnya dengan tegas memahami kata nafs wahidah dalam arti Adam. Buku tafsir ini mengkalim -atas nama mayoritas mufasir- bahwa Adam adalah manusia pertama yang diciptakan Allah. Dari diri ada inilah diciptakan pasangannya, Hawa. Sikap serupa juga dilakukan Didin Hafiduddin dalam tafsir al-Hijri. Namun, ia tidak memberikan penjelasan lebih detail mengenai soal diciptakannya Hawa dari Adam itu: apakah dari tulang rusuk adam atau dan unsur yang jelas sejenis dengannya. ${ }^{67}$

Akhirnya Gusmian mengahiri dengan mengemukakan pendapatnya bahwa secara keseluruhan kita bisa melihat bahwa visi gerak karya tafsir di atas merepresentasikan kecenderungan yang berbeda-beda. Tafsir kebencian, Tafsir bi al Ra'yi dan Argument Kesetaraan Gender sangat tegas menolak pendapat bahwa perempuan (Hawa) diciptakan dari Adam. Dilihat dari rjukan episteme yang dipakai, dalam kasus ini. Tiga buku tafsir ini tampak tidak hanya cukup kental membangun preposisi hermeneutik feminis yang dicanangkan oleh para feminis muslim seperti Fatima Mernisi, Riffat Hasan dan Amina Wadun Muhsin, tetapi juga melihat rasionalitas teks di dalam maupun di luar struktur teks itu sendiri, secara epitemologis, ketiga karya

\footnotetext{
${ }^{65}$ Ibid., p. 335.

${ }^{66}$ Ibid.

${ }^{67}$ Ibid., p. 336.
} 
tafsir ini bertitik tolak pada terma kunci yang dipakai al-Quran kemudian menarik suatu signifikansi pokok, dan dari signifikansi itulah mereka merumuskan al-Quran yang tak terkatakan dalam teks. ${ }^{68}$

Sedangkan Quraish dalam Tafsir al-Mishbah dan Wawasan Al-Quran, Didin dalam Tafsir al-Hijri dan Tim badan wakaf UII dalam al-Quran dan Tafsirnya, tidak langsung proposisi para feminis muslim semacam itu. Secara epistimologis keempat tafsir itu menegaskan yang sebaliknya. Didin dan Tim Badan Wakaf UII dengan tegas berpihak pada pendapat pertama, tetapi keduanya secara epistemoligis tidak memberikan penjelasan mengapa mereka berpendapat demikian. Quraish yang cenderung tidak menolak model pendapat pertama, mendasarkan pendapatnya pada tuntutan konteks ayat bahwa nafs wâhidah dalam QS. Al-Nisa (4): 1 lebih sesuai dimaknai sebagai Adam. Namun dengan model metode interaksi, dua karya tafsir Quraish itu lebih suka berlindung di balik pendapat ulama yang dirujuknya, sehingga ia tidak memperlihatkan pendapatnya sendiri secara tegas. ${ }^{69}$

Di samping itu, kecenderungan Quraish pada pendapat pertama dibarengi dengan pencitraan yang setidaknya ada dua alasan pokok. Pertama, Pasangan Adam yang diciptakan dari tulang rusuknya, bagi Quraish bukan berarti bahwa kedudukan wanita selain Hawa, lebih rendah ketimbang pria. Semua pria dan wanita anak cucu Adam lahir dari gabungan wanita dan pria. Karena itu tidak ada perbedaan dari segi kemanusiaan antara keduanya. Kedua, kekuatan laki-laki dan Quraish dibutuhkan oleh wanita dan kelemahlembutan wanita didambakan oleh pria. Dengan metafor antara jarum dan kain, ia menjelaskan bahwa jarum harus lebih kuat dari kain, dan kain harus lebih lembut dari jarum. Kalau tidak, jarum tidak akan berfungsi, dan kain pun tidak akan terjahit. ${ }^{70}$

Lewat dua alasan itu, Quraish sebetulnya melakukan pewacanaan yang menyembunyikan problem-problem pokok dari relasi laki-laki perempuan. Pada alasan pertama, Quraish tidak melihat aspek psikologis dari konstruksi nalar tentang kisah penciptaan Hawa dari tulang rusuk Adam. Memang, seperti logika yang dipakai, kita akan mengakui bahwa generasi anak cucu Adam (baik laki-laki) maupun perempuan) lahir dari hasil perkawinan dua jenis manusia: laki-laki maupun perempuan. Namun

\footnotetext{
68 Ibid.

${ }^{69}$ Ibid., pp. 336-337.

${ }^{70}$ Ibid., p. 337.
} 
pokok persoalannya tidaklah berhenti pada kesetaraan semacam ini. Sebab, kisah keterciptaan Hawa dari tulang rusuk Adam, secara psikologis telah mengkonstruksi nalar dan bahkan menjadikan suatu pandangan dunia, bahwa perempuan adalah jenis manusia kelas dua, karena asal-usul keterciptaan Hawa tersebut. ${ }^{71}$

Pada alasan kedua, Quraish telah memberikan pencitraan bias gender. Kelembutan perempuan yang di gambarkan seperti kain, dan kekuatan laki-laki yang dia gambarkan seperti jarum, yang saling membutuhkan, jelas merupakan soal gender. Sebab, kekuatan dan kelembutan bukanlah dua hal yang bersifat kodrati, tetapi lebih sebagai suatu potensi dari hasil konstruksi pencitraan dalam wilayah sosial budaya. Oleh karena itu, secara seksual, jarum tidaklah identik dengan jenis kelamin laki-laki, dan kain pun juga tidak identik dengan jenis kelamin perempuan. ${ }^{72}$

Semua analisis di atas memberikan pemahaman bahwa eksistensi, ruang sosial penafsir, konteks dan zaman di mana tafsir itu ditulis, sangat mempengaruhi visi dan arah gerak tafsir. Zaitunah dan Nasaruddin umar, yang keduanya banyak bergumul dengan preposisi hermeneutik feminis, telah membangun episteme yang khas feminis. Sebagai sosok perempuan, secara ideologis, Zaitunah membangun episteme feminis, untuk menemukan icon kesetaraan sebagai dasar visi al-Quran. Dengan jelas dan lugas dia memaparkan dasar-dasar epistemologis dari konsepsi yang dia bangun. Fenomena ini jelas berbeda dengan yang terjadi pada Quraish dan Didin, atau bahkan tim Badan Wakaf UII. ${ }^{73}$

Dari penjelasan yang dikemukan Gusmian dan membaca artikel pembanding yang ada diinternet, dan penjelasan langsung Quraish pada tafsir al-Misbah, Gusmian pun tidak lepas dari tendensius, kita berupaya menjelaskan pemikiran Qiraish dan mengelompokkan Nasaruddin dan Zaitunah. Begitu juga pada awal masalah ketika pentafsiran al-Quran terjadi beberapa contoh yang ditemukan adalah pentafsiran alQuran lebih banyak dirujuk salah dari mufasir yang membela ideology Syiah dan sekarang berita-berita di internet mengatasnamakan alhlususunnah wal jamah mengambil contoh seperti pentafsiran al-Quran yang saya kemukakan di atas, dan kesalahan ini di jatuhkan kepada kaum Syiah. Saya melihat ini juga tidak lepas dari

\footnotetext{
${ }^{71}$ Ibid., pp. 337-8.

${ }^{72}$ Ibid., p. 338.

${ }^{73}$ Ibid.
} 
tendesius menjatuhkan sesama umat Islam. Dan sangat terlihat ahlussunah dan Syiah saling mengklaim menyalahkan.

\section{Pentafsiran Al-Quran dan Realitas Umat: Fakta dan Nasehat Ahmad Syafii Maarif $^{4}$}

Pada awal tulisannya Ahmad Syafii Maarif mengemukakan fakta menurut dia jika kita mau jujur, sebenarnya sudah lama al-Quran tidak lagi berfungsi sebagai petunjuk untuk urusan-urusan besar umat Islam, seperti urusan kenegaraan, ekonomi, hubungan international, dan lain-lain. Bahwa al-Quran masih diimani sebagai kitab suci yang tahan bantingan sejarah, adalah pula sebuah fakta, setidaknya secara formal. Tetapi bahwa kitab ini sudah diabaikan sebagai acuan dalam memecahkan masalah penting umat Islam juga adalah fakta yang lain pula. ${ }^{75}$

Maarif mengemukakan umat Islam pada tataran terkurung menyalahkan satu sama lain. Masing-masing merasa yang paling benar, sementara saudaranya yang lain palsu belaka, jika perlu dihancurkan. Parameter yang digunakan untuk saling menghancurkan itu sungguh sangat rapuh, tetapi diakui sebagai yang benar. ${ }^{76}$ Maarif memperkokoh argumennya ini dengan memberikan contoh yaitu gejala yang semakin kentara di awal abad ke 21 ini adalah polarisasi antara kelompok puritan dan moderat ${ }^{77}$. Masing-masing merasa berada di jalan lurus. Kaum puritan tampak mengkristal dalam format Taliban dan sampai batas tertentu di kalangan orang Arab Saudi. Mereka ini

74 Prof. Dr. h. Ahmad Syafii Maarif lahir di Sumatera Barat, 31 mei 1935adalah seorang ulama, ilmuwan dan pendidik Indonesia. ia pernah menjabat ketua umum pengurus pusat muhammadiyah, presiden world conference on religion for peace (WCRP) dan pendiri Maarif Institute, dan juga dikenal sebagai seorang tokoh yang mempunyai komitmen kebangsaan yang tinggi, sikapnya yang plural, kritis, dan bersahaja telah memposisikannya sebagai "bapak bangsa". Lihat dalam https://id.wikipedia.org/wiki/Ahmad_Syafii_Maarif

${ }^{75}$ Ahmad Syafii Maarif, Al-Quran dan Realitas Umat, (Jakarta: Republika, 2010), p. 1.

${ }^{76}$ Ibid.

${ }^{77}$ Chafid Wahyudi, Tipologi Islam Moderat Dan Puritan: Pemikiran Khaled M. Abou el-Fadl menjelaskan pengolongan yang dilakukan Khaled M. Abou el-Fadl. Abou Fadl menawarkan istilah -moderat dan - puritan. Apa yang dikehendaki oleh Abou el-Fadl dengan istilah moderat, yaitu menjadi tipikal orang moderat adalah, tatkala dihadapkan pada dua pilihan ekstrem, maka selalu memilih jalan tengah. Kemudian berbeda dengan Islam puritan memperlakukan Islam secara kaku dan tidak dinamis. Mereka sangat membesar-besarkan peran teks dan memperkecil peran aktif manusia dalam menafsirkan teks keagamaan. Dalam hal ini orientasi Islam puritan mendasarkan diri dibalik kepastian makna teks, sehingga implementasi perintah Tuhan, yang seutuhnya dan secara menyeluruh seakan sudah termaktub di dalam teks, bukan pada nuansa kontekstualisasi. Semangat dalam memperlakukan Islam di antara Islam moderat dan Islam puritan di atas akan semakin jelas perbedaannya dilihat dalam konteks pengambilan hukum Islam dalam file:C:/ Users/ acer/ Downloads/ Tipologi Islam Moderat dan Puritan Pemikiran Khale. pdf 
ingin menciptakan sebuah dunia seperti masa dini Islam, sebagaimana yang dibayangkan. ${ }^{78}$

Mereka anti semua sistem Barat tetapi menikmati hasil teknologinya, seperti mobil dan HP, bahkan teknik membuat bom. Mereka menilai demokrasi dan hak-hak asasi manusia sebagai produk Barat yang harus dilawan karena merusak Islam. Mereka ingin menciptakan sebuah dunia cita-cita berdasarkan tafsiran mereka yang monolitik terhadap al-Quran dan sejarah Nabi. Kelompok ini juga tersebar di berbagai bagian dunia Islam yang umumnya berideologi radikal tunggal: ingin mengubah dunia secara berani dan cepat, sekalipun berisiko pertumpahan darah. Mereka tidak peduli. ${ }^{79}$

Lebih lanjut Maarif menjelaskan, sebenarnya kelompok puritan ini tidak punya tawaran peradaban yang jelas, tetapi relatif terikat ideology tunggal yang fasistis. Diantara doktrin yang mengikat mereka adalah konsep taat kepada pemimpin, hampir tanpa reserve. Karena itu ada yang menafsirkan bahwa mereka adalah faksi totalitarian dengan payung syariat. Mereka memandang enteng kematian, jika mati itu adalah dalam upaya mencari ridha Allah menurut visi mereka. ${ }^{80}$

Kemudian Maarif menjelaskan perbedaan pandangan, kelompok moderat juga mengaku berpegang kepada al-Quran, tetapi umumnya mereka membela gagasan demokrasi dan hak-hak asasi manusia. Mereka tidak risau apakah gagasan itu berasal dari Barat atau timur. Selama gagasan itu mendukung cita-cita al-Quran untuk membumikan keadilan, perdamaian, moralitas, dan hubungan yang elok sesama umat manusia, mengapa harus ditolak. Mereka merasakan keprihatinan saat menonton dunia Islam yang gelap di bawah sistem politik despotisme yang zalim dan korup tetapi sering diberi legitimasi agama. Didorong oleh keprihatinan ini, mereka tidak segan berpendapat bahwa pemerintahan non-Muslim yang adil lebih baik dari pemerintahan Muslim yang zalim dan korup. Mereka sangat kritikal dengan label yang serba Islam, tetapi dalam realitas bertolak belakang dengan pesan universal Islam yang membela keadilan dan suasana hidup rukun sesama umat manusia. Dibandingkan dengan kelompol puritan yang relatif solid, kelompok moderat tidak terikat dengan ideologi tunggal. Islam bagi mereka tetap menjadi peradaban alternatif masa depan, tetapi yang harus dipahami secara cerdas, jujur dan komprehensif dan historis. Mereka sangat

\footnotetext{
${ }^{78}$ Maarif, Al-Quran, pp. 1-2.

${ }^{79}$ Ibid., p. 2.

${ }^{80}$ Ibid.
} 
kritikal terhadap Barat tetapi tidak menolak unsur-unsur peradaban lain yang positif melalui filter agama. ${ }^{81}$

Maarif pun menegaskan itulah gambaran kasar polarisasi umat Islam masa kini dengan mengabaikan varian-varian kecil yang banyak sekali. Kalau demikian, di mana posisi al-Quran? Maarif pun mengajak para akademisi dan umat untuk memikirkan fakta ini, dengan mengemukakan, mari kita sama-sama berpikir keras untuk mencari jalan yang solutif sehingga al-Quran dapat berfungsi kembali sebagai petunjuk tertinggi dalam memecahkan masalah fundamental dan kemelut kemanusian yang tidak pernah usai. Al-Quran juga sebenarnya berfungsi sebagai al-furqân (kriterium pembeda antara yang hak dengan yang batil) tetapi mengapa kita masih saja terpasung dalam polarisasi yang tajam sesama umat Islam).$^{82}$

Nasehat Akhir yang diberikan beliau kepada semuanya adalah Mari kita belajar bersikap jujur dalam memahami al-Quran, buang jauh-jauh subjektivisme sejarah dan kepentingan pribadi. Menurut Al-Quran risalah kenabian adalah sebagai rahmat bagi alam semesta, bukan hanya untuk umat Islam. Realitas terkini adalah umat Islam secara keseluruhan tidak berdaya, banyak energi terbuang secara sia-sia, sehingga sering menjadi bulan-bulanan pihak lain karena memang busuk dari dalam. ${ }^{83}$

\section{F. Penutup}

Kekuatan kepentingan adalah faktor penyebab penyimpangan dalam penafsiran Al-Quran. Kepentingan ini bisa kepentingan pribadi atau aliran yang di percayai seorang mufasir. Sebagaimana yang sekarang terlihat di internet, jika kita cari dengan kata kunci hadits syiah maka contoh-contoh hadits yang dikemukkan oleh Syiah mengenai Aisah atau Umar. Sangat banyak, blogger seperti ini, yang mengutarakan Syiah itu adalah keyakinan yang sesat. Salah satunya adalah blogger Islam.org. Kebencian terhadap Syiah sangat terlihat jelas, apakah informasi ini adalah benar atau tidak masih perlu studi lebih lanjut.

Kemudian, kepentingan ini berkembang tidak hanya pada tuduhan atas Syiah yang menafsirkan Ayat al-Quran sesuai kepentingan mereka, tetapi juga berkembang kepada kajian yang lebih komplek seperti salah satunya yang saya kemukakan pada

\footnotetext{
${ }^{81}$ Ibid., p. 3.

${ }^{82}$ Ibid.

${ }^{83}$ Ibid., pp. 3-4.
} 
makalah saya ini, yaitu kontroversi pendapat mufasir terhadap ayat an-nisa (4): 1. Pengaruh kepentingan sangat jelas terlihat, menurut saya, ketika Zaitunah mengemukakan pendapatnya dan argument-argumentnya yang dikutif oleh Gusmian. Atau ketika Gusmian juga mengutip pendapat Nasaruddin. Gusmian juga mengutip Quraish dan mengatakan bahwa Quraish tidak terlalu kuat membela kesetaraan gender. Namun menurut saya yang menarik adalah pendapat Gusmian dalam memberikan penjelasan terhadap pandangan tokoh-tokoh, Sebenarnya, apakah dia juga tidak memiliki kepentingan.

\section{DAFTAR PUSTAKA}

Ghazali, Dede Ahmad dan Heri Gunawan. Studi Islam Suatu Pengantar Dengan Pendekatan Interdisipliner, Bandung: PT Remaja Rosdakarya, 2015.

Gusmian, Islah. Khazanah Tafsir Indonesia dari Hermeneutika hingga Ideologi, Yogyakarta: LKiS, 2013.

Shihab, M. Quraish. Membumikan al-Quran Fungsi dan Peran Wahyu dalam Kehidupan dan Masyarakat, Bandung: Mizan, 1992.

Baidan, Nashruddin, Rekonstruksi Ilmu Tafsir, Jakarta: PT Dana Bhakti Prima Yasa, 2000.

Pamungkas, Singgih. Mengenal Syiah antara Syiah dan Rafidhah, https://muslim.or.id/25664-mengenal-syiah-antara-syiah-dan-rafidhah.html.

Yusnatali, Nasihat dan kajian: Siapakah Syiah, http:// yusnatali. dosen. akademitelkom.ac.id/index.php /nasihat-dankajian/ siapakah-syiah/, diakses 24 September 2017.

Permana, Rian. Syiah Mencela Umul Mukmin, Aisah, https://muslim .or.id/8759-syiahmencela-ummul-mukminin-aisyah.html, 25 Maret 2015.0pen Dictionary Wikipedia, https://id.

Norhidayat, Tafsir Kebencian, http://chaqoqo.blogspot.co.id/2011/11/tafsir-kebenciankarya-zaitunah-subhan.html Oleh: Alumni UIN Jakarta Selasa, 22 November 2011.

Dicyionary Wikipedia, https://en.wikipedia.org/wiki/Riffat_Hassan dan Lihat, Liputan Islam, Kajian Islam Tafsir Wacana Tafsir Indonesia Perempuan tercipta dari Tulang Rusuk Laki-Laki, dalam, http://liputanislam.com/kajianislam/tafsir/wacana-tafsir-indonesia-perempuan-tercipta-dari-tulang-rusuklaki-laki2/.

Liputan Islam, Kajian Islam Tafsir Wacana Tafsir Indonesia Perempuan tercipta dari Tulang Rusuk Laki-Laki, dalam, http://liputanislam.com/kajianislam/tafsir/wacana-tafsir-indonesia-perempuan-tercipta-dari-tulang-rusuklaki-laki2/.

Umar, Nasaruddin. Misteri Nafs al-Wahidah, dalam https://paramadina.wordpress.com/2007/03/16/misteri-nafs-al-wahidah/, diakses 16 Maret 2007. 
Mawa'izh

Jurnal Dakwah dan Pengembangan Sosial Kemanusiaan

Vol. 8, no. 1 (2017), pp. 1-30

Wahyudi, Chafid. Tipologi Islam Moderat Dan Puritan: Pemikiran Khaled M. Abou el-Fadl, Dalam,file:///C:/Users/acer/Downloads/Tipologi_Islam_Moderat_dan_Puritan_ Pemikiran_Khale.pdf 